\title{
Stress elevates corticotropin-releasing factor (CRF) and CRF-binding protein mRNA levels in rainbow trout (Oncorhynchus mykiss)
}

\author{
C Doyon, V L Trudeau and T W Moon \\ Centre for Advanced Research in Environmental Genomics (CAREG), Department of Biology, University of Ottawa, Ottawa, Ontario K1N 6N5, Canada \\ (Requests for offprints should be addressed to V L Trudeau; Email: trudeauv@uottawa.ca) \\ (C Doyon is now at Département d'anatomie et de physiologie, Faculté de médecine, Université Laval, Québec, Québec G1K 7P4, Canada)
}

\begin{abstract}
The objectives of this study were to characterize rainbow trout (Oncorhynchus mykiss) corticotropin-releasing factor (CRF)-binding protein (CRF-BP) cDNA and to examine the variations in CRF-BP and CRF mRNA levels in response to different intensities of stress. Trout were physically disturbed by a single or three consecutive periods of chasing until exhaustion followed by $2 \mathrm{~h}$ of recovery. The pituitary CRF-BP and preoptic area CRF1 mRNA contents were significantly increased only after repeated chasing events. Physical disturbance increased plasma cortisol levels with the largest change occurring in the group of trout that were exposed to repeated chasing events. Trout were also individually isolated in 1201 tanks or confined to 1.51 boxes for 4,24 or $72 \mathrm{~h}$. CRF-BP mRNA levels in confined fish were greater than those of
\end{abstract}

isolated fish at $72 \mathrm{~h}$ although there were no differences compared with the control group. CRF1 mRNA levels in the preoptic area were greater and remained elevated for a longer period in confined compared with isolated trout. Isolation led to a transient increase in plasma cortisol levels, but the higher cortisol values developed in the confined fish suggest that this treatment was more stressful than isolation. These results demonstrate that the intensity and duration of stress are important factors regulating CRF and CRF-BP mRNA levels in rainbow trout. We hypothesize that pituitary CRF-BP is involved in regulating the activity of the stress axis, possibly by reducing access to CRF1 receptors in the corticotropes.

Journal of Endocrinology (2005) 186, 123-130

\section{Introduction}

The primary stress response involves the activation of hypothalamic neurons producing corticotropin-releasing factor (CRF), an initial step in the cascade that leads to the synthesis and release of glucocorticoids (Wendelaar Bonga 1997). The activity of the stress axis can be modulated at several levels including pituitary changes in the expression of the CRF1 receptor or CRF-binding protein (CRF$\mathrm{BP})$. The function of CRF-BP is still unclear although studies do support an inhibitory role for CRF-BP on CRF action (Seasholtz et al. 2002). Rodent CRF-BP blocks CRF-induced adrenocorticotropic hormone (ACTH) release from pituitary cells in vitro (Potter et al. 1991, Cortright et al. 1995). Also, CRF released by the human placenta rises exponentially during pregnancy (McLean et al. 1995), but most plasma CRF is bound to its binding protein and therefore unable to bind to its receptors (Zhao et al. 1997). The binding of CRF to plasma CRF-BP would prevent inappropriate stimulation of the stress axis by placental CRF (Petraglia et al. 1993). CRF-BP is present in corticotropes of the anterior pituitary of rodents, implying that it could modulate the action of receptor- bound CRF (Seasholtz et al. 2002). In a line of transgenic mice overexpressing CRF-BP in the anterior pituitary only, it was hypothesized that the elevated hypothalamic CRF expression observed may have a role to maintain normal levels of free CRF and normal activity of the stress axis (Burrows et al. 1998). The levels of CRF-BP mRNA in the rat pituitary were increased by stress and decreased by adrenalectomy, suggesting a possible involvement of pituitary CRF-BP in regulating the activity of the stress axis (McClennen et al. 1998). Recent evidence supports a function for CRF-BP other than simply inhibiting CRF action in the central nervous system of rodents. The CRF$\mathrm{BP}$ ligand inhibitor, $\mathrm{CRF}_{6-33}$, activated some neurons that express CRF-BP but not CRF receptors, implicating CRF-BP in signalling by CRF-related peptides (Chan et al. 2000). Also, CRF required CRF-BP to potentiate $\mathrm{N}$-methyl-D-aspartate (NMDA) receptor-mediated synaptic transmission in dopamine neurons (Ungless et al. 2003).

Fish may represent a good model to study the regulation and role of pituitary CRF-BP because of the direct innervation of corticotropes within the pituitary pars distalis by CRF-containing nerve fibers (Yulis \& Lederis 1987, Olivereau \& Olivereau 1988). Although CRF-BP 
was not detected in the plasma of tilapia (Pepels et al. 2004), CRF-BP-like immunoreactivity was localized in the pituitary gland of common carp (Huising et al. 2004). The objectives of this study were therefore to characterize rainbow trout CRF-BP CDNA and to examine the effects of different intensities of stress on CRF-BP and CRF1 mRNA levels. We recently characterized the cDNA encoding two paralogous forms of rainbow trout (Oncorhynchus mykiss) CRF, CRF1 and CRF2, and we demonstrated that social stress increased CRF1 mRNA levels in the preoptic area of the trout brain (Doyon et al. 2003). CRF1 mRNA content was examined in the preoptic area, which contains the highest levels of brain CRF mRNA (Doyon et al. 2003). CRF-BP mRNA levels were measured in the pituitary gland, one potential site for CRF-BP regulation of the stress axis activity. Various intensities of stress were achieved by physically disturbing trout with single or repeated chasing events and by isolating trout individually in large tanks or small confinement boxes for 4, 24 or $72 \mathrm{~h}$. CRF-BP and CRF1 mRNA levels were measured by a ribonuclease protection assay (RPA). Based on results from previous studies (Doyon et al. 2003), we hypothesized that stress would increase pituitary CRF-BP and preoptic area CRF1 mRNA contents.

\section{Materials and Methods}

Animals

Immature female rainbow trout, Oncorhynchus mykiss, were obtained from Linwood Acres Trout Farm (Campellcroft, ON, Canada). They were acclimated to the laboratory for at least 6 weeks in 12751 fiberglass tanks of well-aerated dechloraminated City of Ottawa tap water at $13 \pm 1{ }^{\circ} \mathrm{C}$ with a constant 12 -h light/12-h dark photoperiod. Holding tanks initially contained approximately 250 fish with an average weight of approximately $75 \mathrm{~g}$ each. Fish were fed three times per week with commercial trout pellets (Classic Floating Trout Grower; Martin Mills, Tavistock, ON, Canada). These experiments were approved by the University of Ottawa Animal Care Committee (protocol number BL-160) under guidelines applied by the Canadian Council on Animal Care.

\section{Physical-disturbance protocol}

Physical-disturbance experiments were carried out from December 2002 to March 2003 and used a total of 40 trout weighing between 35 and $97 \mathrm{~g}(63 \cdot 2 \pm 2 \cdot 3 \mathrm{~g})$. Over this period, 16 trout were netted quickly at a rate of two to four fish per sampling day from a 12751 holding tank that had not been disturbed by netting for at least 2 days. These fish were immediately anaesthetized for use as unstressed controls. 12 trout were netted from the same holding tank as the controls at a rate of six fish per sampling day. These fish were physically disturbed individually by continuous chasing until exhaustion (approximately $5 \mathrm{~min}$ ) followed by anaesthesia after a $2-\mathrm{h}$ recovery period in individual 1201 isolation tanks. An additional 12 trout were subjected to three consecutive periods of chasing with a 2-h recovery period after each disturbance. Hence, fish exposed to repeated disturbances were anaesthetized $6 \mathrm{~h}$ after the beginning of the first chasing event.

\section{Isolation protocol}

Isolation experiments were carried out in August and September 2002, and used a total of 86 trout weighing between 57 and $136 \mathrm{~g}(96 \cdot 1 \pm 2 \cdot 2 \mathrm{~g})$. Over this period, 14 trout were netted quickly at a rate of two to four fish per sampling day from a 12751 holding tank that had not been disturbed by netting for at least 2 days. These fish were immediately anaesthetized for use as unstressed controls. 72 trout were netted from the same holding tank as the controls at the rate of four to eight fish per sampling day. These fish were isolated individually in either 1201 fiberglass tanks (isolated fish) or 1.51 black plexiglass confinement boxes (confined fish). For each experimental treatment, 12 fish were anaesthetized after 4, 24 and $72 \mathrm{~h}$ of isolation or confinement. As the available confinement boxes were black, the 1201 tanks were covered to maintain all fish in total darkness.

\section{Hormone measurements}

Fish were netted quickly and terminally anaesthetized in $150 \mathrm{mg} 1^{-1}$ benzocaine (ethyl $p$-aminobenzoate; SigmaAldrich, St Louis, MO, USA). All fish were anaesthetized between 2 and 4 p.m. to avoid possible daily rhythms of plasma cortisol. Blood was collected in heparinized syringes by caudal puncture and centrifuged. The plasma was removed and stored at $-80{ }^{\circ} \mathrm{C}$ for later analysis of cortisol levels using a commercially available RIA kit (Cortisol ${ }^{125}$ I RIA Kit; ICN Diagnostics, Costa Mesa, CA, USA).

\section{Amplification of CRF-BP-related cDNA fragments and sequencing}

Poly $(\mathrm{A})^{+}$RNA was extracted from the preoptic area of the trout brain using the Straight As mRNA Isolation System (Novagen, Madison, WI, USA). Oligonucleotide primers (Invitrogen, Burlington, ON, Canada) were designed on the basis of high sequence identity between the Xenopus laevis (Brown et al. 1996) and the Japanese pufferfish CRF-BP sequences (Table 1). First-strand cDNA was synthesized from $400 \mathrm{ng}$ poly(A) ${ }^{+}$RNA with Superscript II (Invitrogen) and oligo(dT). Amplification was carried out using Taq polymerase (Invitrogen) and a Mastercycler 
Table 1 Primer sequences used for cloning and amplification of template DNA for the RPA

\begin{tabular}{|c|c|c|c|c|}
\hline & $5^{\prime}$ Primer & Position & 3' Primer & Position \\
\hline \multirow{3}{*}{$\begin{array}{l}\text { Initial cloning } \\
\text { 5' RACE GSP1 } \\
\text { 5' RACE GSP2 }\end{array}$} & GGTGTTTGATGGCTGGGTAA & $395-414$ & AGCTGCAGTTCCTGTGCTG & $603-681$ \\
\hline & & & TGACTGTCAGCGTGAAGGAG & $566-585$ \\
\hline & & & TCCACATAGCGTTCCATCAA & $459-478$ \\
\hline \multirow[t]{2}{*}{ RPA CRF-BP } & ATTAGGTGACACTATAGA & $615-630$ & TAATACGACTCACTATAGGG & $830-845$ \\
\hline & АTCАТСТСССАGАСАC & & AGCTACAGGGAACATT & \\
\hline RPA $\beta$-actin & ATITAGGTGACACTATAGAAGVC & 274-292 & TAATACGACTCACTATAGGGAGA & $593-611$ \\
\hline
\end{tabular}

Nucleotides in italics represent the promoter sequences for T7 and SP6 RNA polymerases. GSP, gene-specific primer; RACE, rapid amplification of cDNA ends.

Gradient (Eppendorf; Mississauga, ON, Canada) with the following program: $5 \mathrm{~min}$ denaturation at $94{ }^{\circ} \mathrm{C}$, followed by 35 cycles of denaturation at $94^{\circ} \mathrm{C}$ for $30 \mathrm{~s}$, annealing at $55{ }^{\circ} \mathrm{C}$ for $30 \mathrm{~s}$ and extension at $72{ }^{\circ} \mathrm{C}$ for $1 \mathrm{~min}$. After the last cycle, further extension was performed at $72{ }^{\circ} \mathrm{C}$ for $10 \mathrm{~min}$. The PCR reaction contained $4 \mu \mathrm{l}$ cDNA in a $50 \mu \mathrm{l}$ PCR reaction.

The $3^{\prime}$ and $5^{\prime}$ ends of trout CRF-BP were obtained by rapid amplification of cDNA ends (RACE; Invitrogen). For 3' RACE, first-strand cDNA was synthesized from $400 \mathrm{ng} \operatorname{poly}(\mathrm{A})^{+}$RNA with Superscript II and the $3^{\prime}$ RACE adapter primer (Invitrogen). CRF-BP-related cDNA fragments were amplified using the sense primer of the initial cloning procedure (Table 1), the abridged universal amplification primer (AUAP; Invitrogen) and the program described above. For 5' RACE, total RNA was extracted from the preoptic area using TRIzol reagent (Invitrogen). First-strand cDNA was synthesized from $700 \mathrm{ng}$ total RNA with Superscript II and the antisense primer of the initial cloning procedure (Table 1). The cDNA was purified after each step of the $5^{\prime}$ RACE with the QIAquick PCR Purification Kit (Qiagen). Tailing of the $5^{\prime}$ end of the cDNA was performed using dCTP and terminal transferase (Roche, Laval, QC, Canada). The first PCR reaction was performed using the antisense primer of the initial cloning procedure (Table 1). Two seminested PCR reactions were performed using gene-specific primers (GSP1 and GSP2; Table 1) that were based on initial sequencing results.

Amplified CRF-BP products were extracted from a $1 \%$ agarose gel with the QIAquick Gel Extraction Kit (Qiagen), ligated into the pCR II-TOPO cloning vector (TOPO TA cloning kit; Invitrogen), and transformed into Escherichia coli competent cells (One Shot TOP10 Chemically competent cells; Invitrogen). Single colonies were cultured and plasmids were recovered with Wizard Plus (Promega, Madison, WI, USA). All procedures were carried out according to the manufacturer's instructions. Both strands of at least three different cloned inserts were sequenced (Canadian Molecular Research Services, Ottawa, ON, Canada) to obtain the reported consensus sequence. Nucleotide sequences were submitted to
BLAST (http://www.ncbi.nlm.nih.gov/blast/blast.cgi; Altschul et al. 1997) for comparison with sequences present in the GenBank nucleotide sequence database.

\section{$R P A$}

Total RNA was extracted from the preoptic area of the brain (which also included part of the anterior hypothalamus) and pituitary glands using TRIzol reagent. Levels of CRF1 and $\beta$-actin mRNA in the preoptic area were analyzed using the RPA (RPA III; Ambion, Austin, TX, USA) described previously (Doyon et al. 2003). Levels of CRF-BP and $\beta$-actin mRNA in individual pituitaries were determined using a separate RPA (RPA III). The DNA templates for the preparation of antisense RNA probes were generated by PCR using primers with incorporated SP6 and T7 phage polymerase promoters on the sense and antisense primers, respectively (Table 1). DNA templates were amplified using the following program: 3 min denaturing at $94{ }^{\circ} \mathrm{C}$, then 35 cycles of denaturation at $94{ }^{\circ} \mathrm{C}$ for $30 \mathrm{~s}$, annealing at $58{ }^{\circ} \mathrm{C}$ for $30 \mathrm{~s}$ and extension at $72{ }^{\circ} \mathrm{C}$ for $1 \mathrm{~min}$. After the last cycle, further extension was performed at $72{ }^{\circ} \mathrm{C}$ for $7 \mathrm{~min}$. Amplified products were extracted from a 1\% agarose gel with the QIAquick Gel Extraction Kit. Antisense RNA probes were prepared using the MAXIscript In vitro Transcription Kit (Ambion) and approximately $100 \mathrm{ng}$ template DNA.

For CRF-BP, probes were prepared by incubating the DNA at $37{ }^{\circ} \mathrm{C}$ for $30 \mathrm{~min}$ with $40 \mu \mathrm{Ci}\left[\alpha_{-}{ }^{32} \mathrm{P}\right] \mathrm{CTP}$ at 800 $\mathrm{Ci} \mathrm{mmol}^{-1}$ (Amersham Bioscience, Baie d'Urfé, QC, Canada) in the presence of $0.05 \mathrm{mM}$ unlabeled CTP. To limit the hybridization signal of $\beta$-actin, a highly expressed gene, reduced-specific-activity probes were prepared by incubating the DNA at $37^{\circ} \mathrm{C}$ for $1 \mathrm{~h}$ with $40 \mu \mathrm{Ci}$ $\left[\alpha-{ }^{32} \mathrm{P}\right] \mathrm{CTP}$ at $800 \mathrm{Ci} \mathrm{mmol}{ }^{-1}$ (Amersham Bioscience) in the presence of $0.5 \mathrm{mM}$ unlabeled CTP. The transcription products were incubated for $30 \mathrm{~min}$ at $37^{\circ} \mathrm{C}$ with 5 units of RNase-free DNase 1 (Promega). Full-length probes were purified from a $5 \%$ acrylamide/bis-acrylamide (19:1)/8 M urea gel. Approximately $8 \times 10^{4}$ c.p.m. probe was hybridized overnight at $42{ }^{\circ} \mathrm{C}$ to $10 \mu \mathrm{g}$ total RNA. Non-hybridized transcripts were digested at $37^{\circ} \mathrm{C}$ for 
A
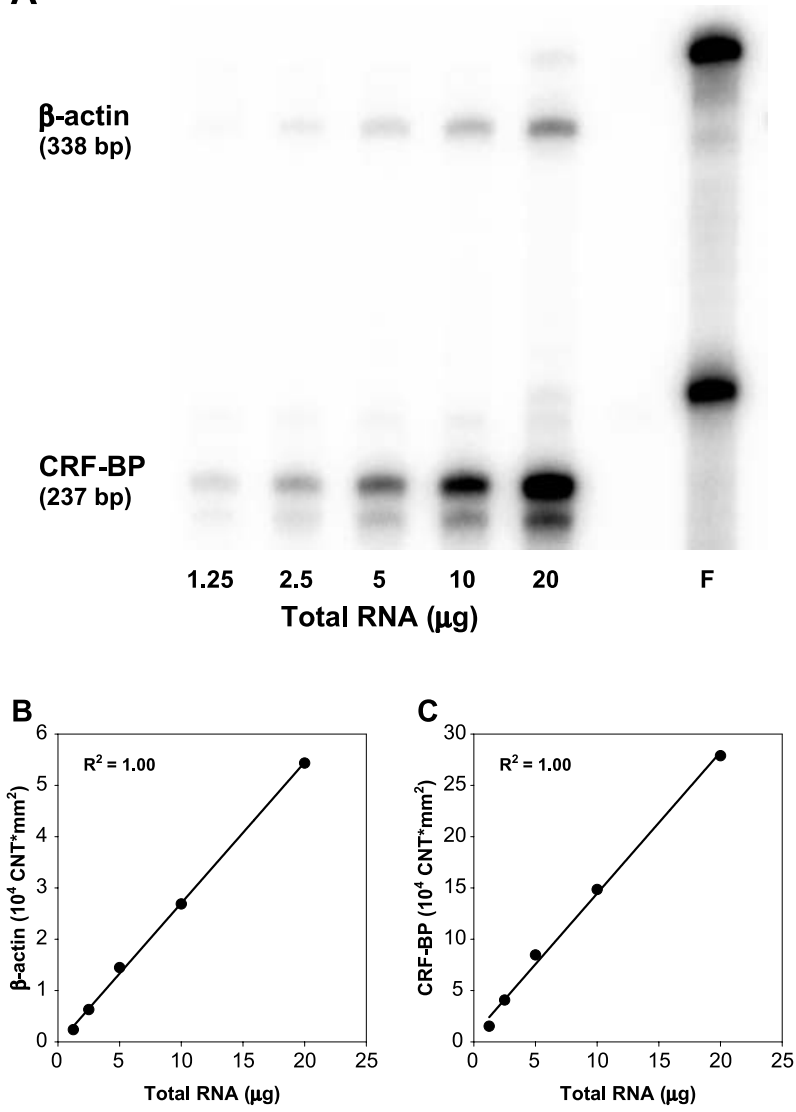

Figure 1 A representative RPA gel illustrating the increases in band density that occurred with increasing amounts of pituitary total RNA (A), and representative standard curves demonstrating that the measured levels of $\beta$-actin (B) and CRF-BP (C) mRNA increase linearly with the amount of pituitary total RNA used in the RPA. The lane labelled $F$ in $(A)$ contains the undigested full-length probes. The correlation coefficients of the linear regressions appear on the graphs. CNT* $\mathrm{mm}^{2}$, counts per $\mathrm{mm}^{2}$.

30 min with approximately $0 \cdot 2$ units RNase A and $7 \cdot 5$ units RNase T1 (Ambion). Protected fragments were resolved on a 5\% acrylamide/bis-acrylamide (19:1)/8 M urea gel. An Image Screen-K was exposed for $18 \mathrm{~h}$ to the dried gel and the optical density of the bands was analyzed with Quantity One version 4·1·1 (Bio-Rad Laboratories, Mississauga, ON, Canada). Results were expressed in counts per $\mathrm{mm}^{2}$, the arbitrary volume unit of Quantity One. The RPA was optimized by verifying the linearity of the relation between quantified mRNA and the amount of total RNA (Fig. 1). The standard curves for the optimization of the RPA demonstrate linearity and thus the levels of $\beta$-actin (Fig. 1B) and CRF-BP (Fig. 1C) mRNA can be quantified with this technique.

\section{Statistics}

Results are presented as mean values \pm 1 S.E.M. For the isolation experiment, statistical differences between treat- ments were determined by two-way analysis of variance (ANOVA) with a significance level of $P<0 \cdot 05$. For each treatment, statistical differences between time points and control were determined by one-way ANOVA. CRF1 mRNA values for the confined fish were transformed using a natural logarithm to meet the assumption of normality. For the physical-disturbance experiment, statistical differences between treatments were determined by one-way ANOVA. All parametric ANOVAs were followed by Tukey's multiple-comparison tests. For both experiments, data on cortisol content did not meet the assumption of normality so differences between treatments were determined by Kruskal-Wallis one-way ANOVA on ranks followed by Dunn's multiple-comparison test. All statistical analyses used SigmaStat (v2.0) software (SPSS, Chicago, IL, USA).

\section{Results}

\section{Sequencing and characterization of trout CRF-BP}

A complete coding sequence was obtained for the cDNA encoding rainbow trout CRF-BP (GenBank accession no. AY363677). The nucleotide sequence of CRF-BP (1609 $\mathrm{nt}$ ) is composed of a $62 \mathrm{bp} 5^{\prime}$-untranslated region (UTR), a $963 \mathrm{bp}$ open reading frame (ORF) and a $583 \mathrm{bp}$ $3^{\prime}$-UTR that contains two polyadenylation signals (AATAAA). The deduced amino acid sequence (321 amino acids) contains a putative signal peptide of 21 amino acids, as predicted using the SignalP program v2.0 (http:// www.cbs.Dtu.dk/services/SignalP-2.0/; Nielsen et al. 1997, Nielsen \& Krogh 1998). The putative mature peptide contains 10 cysteine residues that are highly conserved throughout vertebrates (Huising et al. 2004) and are likely involved in the formation of five disulfude bonds (trout $\mathrm{C}^{60}-\mathrm{C}^{81}, \mathrm{C}^{104}-\mathrm{C}^{141}, \mathrm{C}^{183}-\mathrm{C}^{205}, \mathrm{C}^{239}-\mathrm{C}^{264}, \mathrm{C}^{277}-$ $\mathrm{C}^{318}$.

\section{Physical disturbance}

The levels of plasma cortisol in controls $(9 \cdot 30 \pm$ $0.66 \mathrm{ng} / \mathrm{ml}$ were characteristic of unstressed trout (Fig. 2A; Barton \& Iwama 1991). One period of physical disturbance led to a significant increase in plasma cortisol levels; levels were further increased after three consecutive chasing events (Fig. 2A). One chasing event was not sufficient to increase CRF1 mRNA content despite elevated cortisol levels (Fig. 2B). However, three chasing events significantly increased CRF1 mRNA levels compared with both the control and a single chasing event (Fig. 2B). A 2-fold increase in pituitary CRF-BP mRNA content was obtained after three chasing events (Fig. 2C).

\section{Isolation}

The levels of plasma cortisol in controls $(1 \cdot 38 \pm 1 \cdot 02 \mathrm{ng} /$ $\mathrm{ml}$ ) were characteristic of unstressed trout (Fig. 3A; Barton 


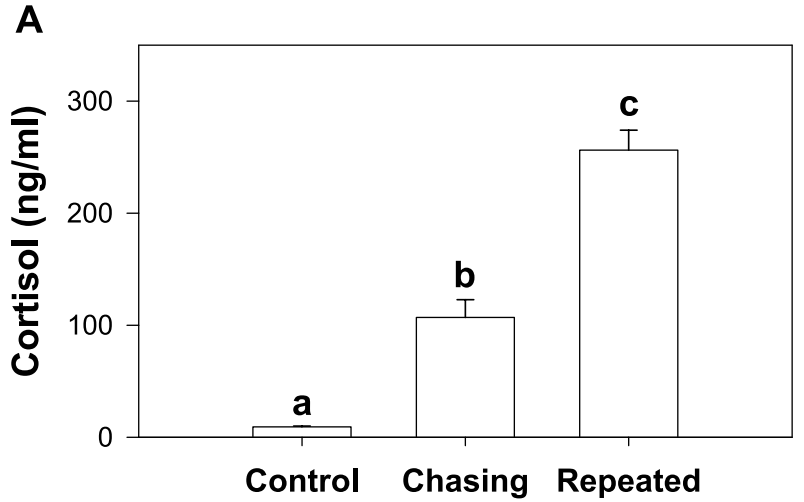

B

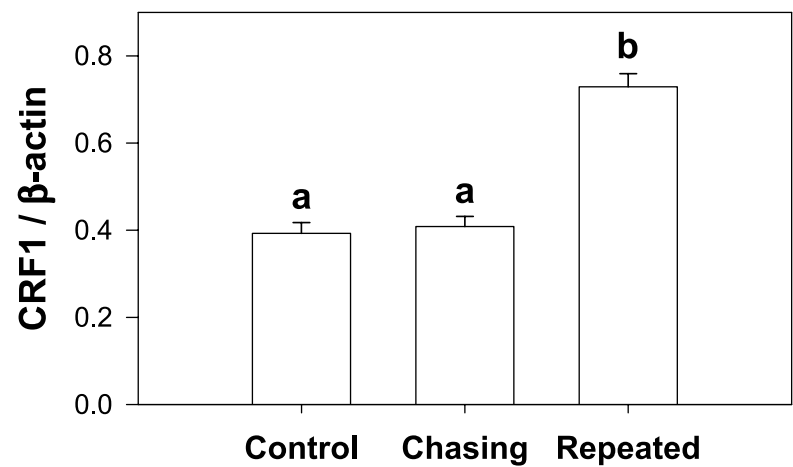

C

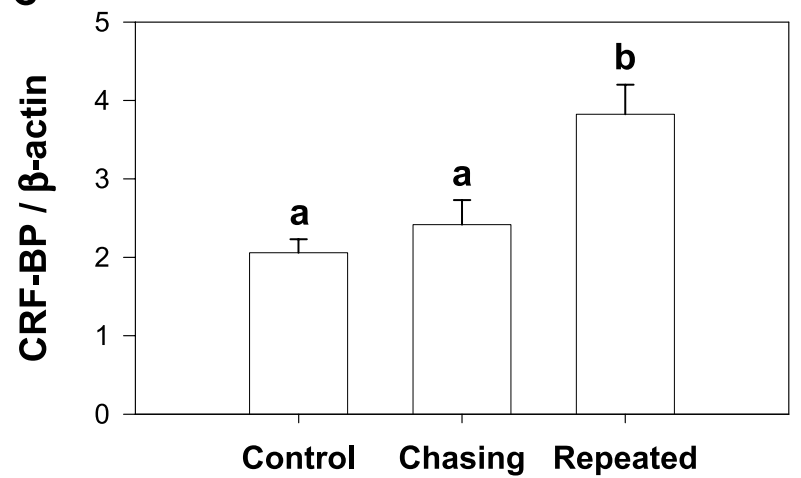

Figure 2 Effects of single and repeated periods of physical disturbance on the levels of (A) plasma cortisol, (B) preoptic area CRF1 mRNA and (C) pituitary CRF-BP mRNA in juvenile female rainbow trout. Measurements were carried out after a single (Chasing) or three consecutive (Repeated) periods of physical disturbance followed by a 2 -h recovery period in isolation. $\beta$-actin was used as a control to correct for the amount of total RNA used in the RPA. Treatments that do not share a common letter are significantly different from each other $(P<0 \cdot 05 ; n=12-16$ per group).

\& Iwama 1991). Plasma cortisol levels in both treatments were significantly elevated compared with the control at 4 and $24 \mathrm{~h}$ of isolation but were back to control values at $72 \mathrm{~h}$ (Fig. 3A). The elevation in plasma cortisol at $4 \mathrm{~h}$ was
A
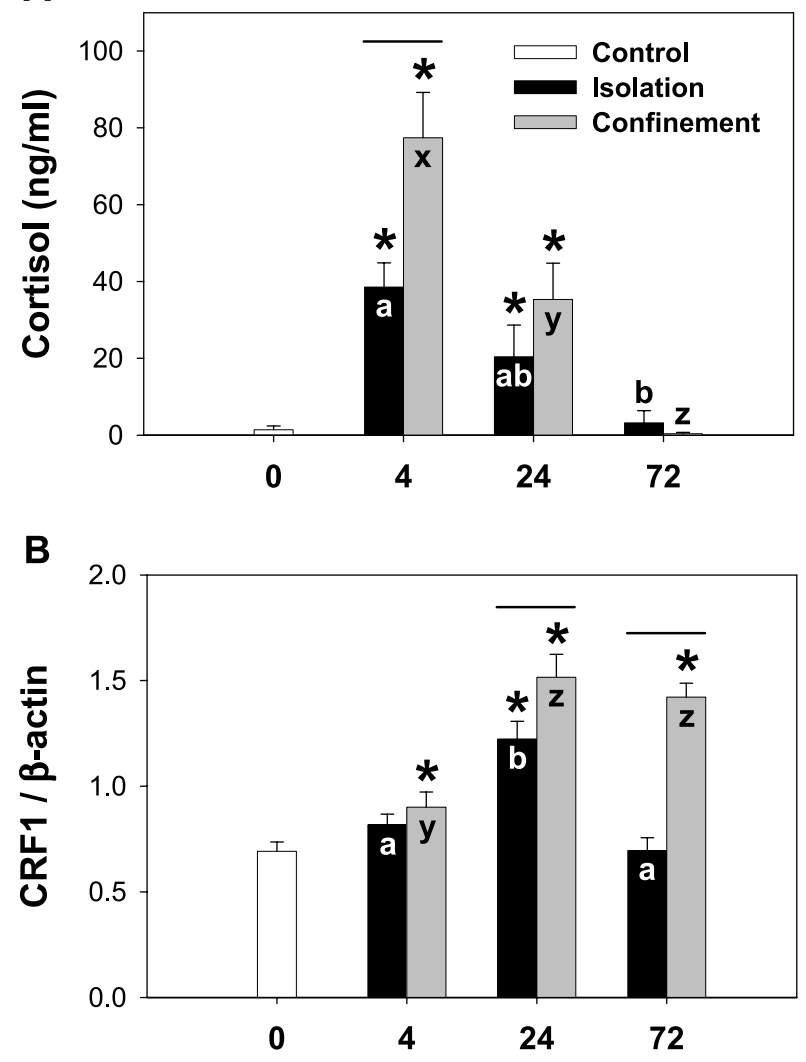

C

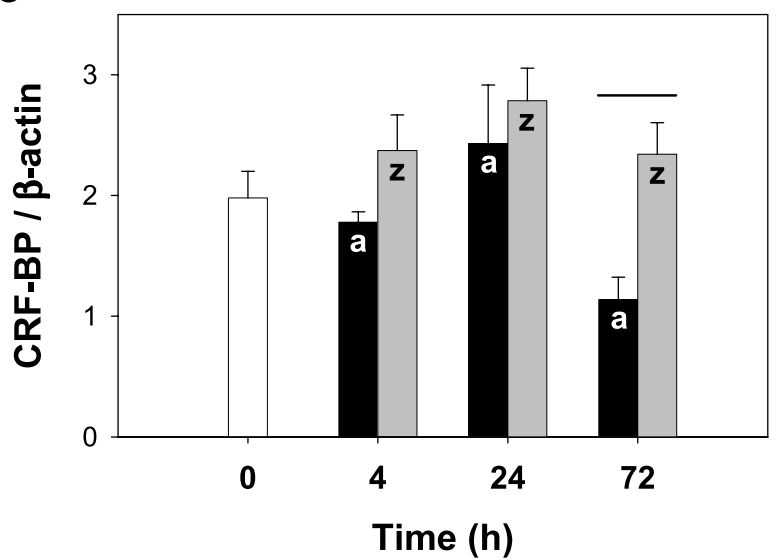

Figure 3 Time course of changes in the levels of (A) plasma cortisol, (B) preoptic area CRF1 mRNA and (C) pituitary CRF-BP mRNA in juvenile female rainbow trout that were individually isolated in $120 \mathrm{I}$ tanks (Isolation) or confined to $1.5 \mathrm{I}$ boxes (Confinement). $\beta$-actin was used as a control to correct for the amount of total RNA used in the RPA. Treatments that do not share a common letter within isolation or confinement are significantly different from each other $(P<0 \cdot 05)$. Asterisks show statistical difference compared with control, whereas horizontal bars show difference between isolation and confinement $(P<0 \cdot 05$; $n=12-14$ per group). 
greater in trout confined in 1.51 boxes compared with trout isolated in a 1201 tank. Although cortisol levels were highest at $4 \mathrm{~h}$ of isolation, CRF1 mRNA levels were different from control values in the confined fish only (Fig. 3B). At $24 \mathrm{~h}$ of isolation, both groups had elevated CRF1 mRNA levels compared with both the control and $4 \mathrm{~h}$ values. CRF1 mRNA levels remained elevated at $72 \mathrm{~h}$ in confined fish despite low cortisol values, whereas levels of CRF1 mRNA were back to control values in isolated fish. The levels of CRF-BP mRNA in the pituitary gland also showed trends that were similar to those of CRF1 mRNA (Fig. 3C). The difference in the levels of CRF-BP mRNA between isolation and confinement groups was only significant at $72 \mathrm{~h}$ although there was no difference compared with the control group.

\section{Discussion}

We report the complete coding sequence for the precursor cDNA of rainbow trout CRF-BP. The predicted amino acid sequence of trout CRF-BP shares $75 \%$ identity with the recently reported sequence of the common carp, Cyprinus carpio (Huising et al. 2004), and approximately $60 \%$ identity with mammalian sequences (Potter et al. 1991). Two distinct forms of the cDNA encoding CRF-BP were reported for the common carp, a tetraploid species (Huising et al. 2004). As the rainbow trout is also tetraploid, more than one form of CRF-BP would be predicted, and preliminary sequencing information of another trout CRF-BP (NJ Bernier, personal communication) appears to substantiate this prediction. The second CRF-BP band on the RPA is consistent with the presence of a second form of CRF-BP in trout (Fig. 1A).

The repeated physical-disturbance stress that led to the highest cortisol levels in this study increased CRF-BP mRNA levels in the trout pituitary gland. Trout exposed to three consecutive chasing events had a 2-fold increase in pituitary CRF-BP mRNA levels. This novel finding contrasts with a common carp study that failed to show a statistically significant increase in CRF-BP mRNA levels in the pars distalis of the pituitary gland following $24 \mathrm{~h}$ of restraint stress (Huising et al. 2004). This discrepancy may be attributable to differences in stress intensity attained between our respective experimental protocols and the natural sensitivities of the two species to stress. Our result is consistent with a study in rats that showed increased pituitary CRF-BP mRNA following an acute restraint stress (McClennen et al. 1998). These results implicate the involvement of CRF-BP in modulating the responsiveness of the stress axis. For example, increased CRF-BP may reduce levels of 'free' CRF, and thus attenuate the activation of the stress axis by reducing access to CRF1 receptors in the corticotropes. Other studies have demonstrated that glucocorticoids increase pituitary CRF-BP mRNA in the rat (Behan et al. 1995, McClennen et al. 1998), leading McClennen et al. (1998) to propose that this may represent a novel mechanism of feedback inhibition of the stress axis by glucocorticoids.

The results of the physical-disturbance experiments provide evidence that the duration of the stress is a determining factor in elevating preoptic CRF mRNA levels. Although one chasing event significantly increased plasma cortisol levels, no detectable change in CRF1 mRNA occured. In a preliminary experiment where we tested different recovery times following a single chasing event (2, 4, 6 and $8 \mathrm{~h}$ ), we observed no differences in CRF1 mRNA levels (results not shown). Three consecutive periods of physical disturbance led to a greater elevation in plasma cortisol and a highly significant increase in CRF1 mRNA levels. Similar results were obtained in common carp exposed to an acute $(30 \mathrm{~min})$ or a prolonged $(24 \mathrm{~h})$ restraint stress; only prolonged restraint was sufficient to increase hypothalamic CRF mRNA levels (Huising et al. 2004). These results are consistent with studies in rats showing that exposure to repeated footshock stress increased CRF mRNA levels in the paraventricular nucleus, whereas a single footshock was not sufficient to produce this effect (Deutch et al. 1987, Imaki et al. 1991). However, $5 \mathrm{~min}$ of immobilization stress was sufficient to increase CRF heteronuclear RNA levels in the rat paraventricular nucleus, implicating activation of CRF transcription (Imaki et al. 1995, 1996). Despite a rapid increase in CRF heteronuclear RNA, elevated CRF mRNA levels were detectable only 60-120 min after the beginning of the stress (Imaki et al. 1992, 1995).

Placing trout individually in either 1201 tanks or 1.51 boxes led to a transient increase in plasma cortisol levels despite continuous exposure to the stressor (4-72 h). Although several studies report transient increases in plasma cortisol with continuous confinement of rainbow trout (Pottinger \& Moran 1993, Gamperl et al. 1994), this is the first study to examine these changes in plasma cortisol in parallel with those of CRF and CRF-BP mRNA. Also, isolation in 1201 tanks led to a transient increase in CRF1 mRNA levels in the preoptic area of the trout brain despite sustained stimulus. Although part of this increase in CRF1 mRNA may result from the initial netting and handling stress, this result implies a habituation to isolation. Such adjustments may contribute to maintaining the responsiveness of the hypothalamic-pituitaryinterrenal (HPI) axis to a novel stressor in situations of chronic stress, as has been observed in chronically stressed mammals (Aguilera 1994).

Plasma cortisol levels were higher in confined fish (1.5 l) compared with fish isolated in a large water volume (120 1). Thus, confinement was more stressful than isolation, and this greater stress intensity was reflected in CRF1 mRNA levels. The magnitude and persistence of the elevation in CRF1 mRNA was greater in confined fish, suggesting a correlation between CRF mRNA levels and 
the intensity of stress in trout. Similarly, brief low-water exposure did not affect arginine vasotocin (AVT) mRNA, whereas acute confinement, which elicited a greater cortisol response, significantly increased AVT transcript levels in parvocellular neurons of the preoptic nucleus of the rainbow trout brain (Gilchriest et al. 2000). AVT co-localizes with CRF in some neurons of the preoptic nucleus in teleost fish (Yulis \& Lederis 1987, Olivereau \& Olivereau 1988) and AVT potentiates the effect of CRF on ACTH release in rainbow trout (Baker et al. 1996).

Isolation and confinement had relatively mild effects on CRF-BP mRNA levels. In confined fish, CRF-BP mRNA levels were greater than those of isolated fish at $72 \mathrm{~h}$ although there was no difference with the control group. Nevertheless, CRF-BP mRNA levels were positively correlated with those of CRF1 in both experimental protocols (physical disturbance, $R^{2}=0 \cdot 26, P<0 \cdot 001$; isolation, $\left.R^{2}=0 \cdot 21, P<0 \cdot 001\right)$. This result supports the idea that both transcripts are regulated by similar factors. However, unlike hypothalamic CRF, pituitary CRF-BP is under positive glucocorticoid control in rodents (Behan et al. 1995, McClennen et al. 1998).

In conclusion, we have characterized the precursor cDNA for rainbow trout CRF-BP. Our results demonstrate that both intensity and duration of stress are important factors determining the magnitude and persistence of the elevation in preoptic area CRF and pituitary CRF-BP mRNA levels in rainbow trout. We hypothesize that pituitary CRF-BP is involved in regulating the activity of the stress axis, possibly by sequestering CRF from its receptor and thus, promoting a more rapid return to homeostasis after stress.

\section{Acknowledgements}

This research was supported by research grants from NSER C-Canada to T W M and V L T. C D was supported by scholarships from NSERC-Canada, FCARQuébec and the University of Ottawa. We wish to thank James Nickerson for providing the $\beta$-actin primers for the RPA, and Dr Nicholas J Bernier for his enlightening discussions of our work. The authors declare that there is no conflict of interest that would prejudice the impartiality of this scientific work.

\section{References}

Aguilera G 1994 Regulation of pituitary ACTH secretion during chronic stress. Frontiers in Neuroendocrinology 15 321-350.

Altschul SF, Madden TL, Schaffer AA, Zhang J, Zhang Z, Miller W \& Lipman DJ 1997 Gapped BLAST and PSI-BLAST: a new generation of protein database search programs. Nucleic Acids Research 25 3389-3402.

Baker BI, Bird DJ \& Buckingham JC 1996 In the trout, CRH and AVT synergize to stimulate ACTH release. Regulatory Peptides 67 207-210.
Barton BA \& Iwama GK 1991 Physiological changes in fish from stress in aquaculture with emphasis on the response and effects of corticosteroids. Annual Review of Fish Diseases 1 3-26.

Behan DP, De Souza EB, Lowry PJ, Potter E, Sawchenko P \& Vale WW 1995 Corticotropin releasing factor (CRF) binding protein: a novel regulator of CRF and related peptides. Frontiers in Neuroendocrinology 16 362-382.

Brown DD, Wang Z, Furlow JD, Kanamori A, Schwartzman RA, Remo BF \& Pinder A 1996 The thyroid hormone-induced tail resorption program during Xenopus laevis metamorphosis. PNAS 93 1924-1929.

Burrows HL, Nakajima M, Lesh JS, Goosens KA, Samuelson LC, Inui A, Camper SA \& Seasholtz AF 1998 Excess corticotropin releasing hormone-binding protein in the hypothalamic-pituitary-adrenal axis in transgenic mice. Journal of Clinical Investigation $\mathbf{1 0 1}$ 1439-1447.

Chan RK, Vale WW \& Sawchenko PE 2000 Paradoxical activational effects of a corticotropin-releasing factor-binding protein 'ligand inhibitor' in rat brain. Neuroscience 101 115-129.

Cortright DN, Nicoletti A \& Seasholtz AF 1995 Molecular and biochemical characterization of the mouse brain corticotropin-releasing hormone-binding protein. Molecular and Cellular Endocrinology 111 147-157.

Deutch AY, Bean AJ, Bissette G, Nemeroff CB, Robbins RJ \& Roth RH 1987 Stress-induced alterations in neurotensin, somatostatin and corticotropin-releasing factor in mesotelencephalic dopamine system regions. Brain Research 417 350-354.

Doyon C, Gilmour KM, Trudeau VL \& Moon TW 2003 Corticotropin-releasing factor and neuropeptide Y mRNA levels are elevated in the preoptic area of socially subordinate rainbow trout. General and Comparative Endocrinology 133 260-271.

Gamperl A, Vijayan M \& Boutilier R 1994 Epinephrine, norepinephrine, and cortisol concentrations in cannulated seawater-acclimated rainbow trout (Oncorhynchus mykiss) following black-box confinement and epinephrine injection. Journal of Fish Biology 45 313-324.

Gilchriest BJ, Tipping DR, Hake L, Levy A \& Baker BI 2000 The effects of acute and chronic stresses on vasotocin gene transcripts in the brain of the rainbow trout (Oncorhynchus mykiss). Journal of Neuroendocrinology 12 795-801.

Huising MO, Metz JR, van Schooten C, Taverne-Thiele AJ, Hermsen T, Verburg-van Kemenade BM \& Flik G 2004 Structural characterisation of a cyprinid (Cyprinus carpio L.) CRH, CRH-BP and $\mathrm{CRH}-\mathrm{R} 1$, and the role of these proteins in the acute stress response. Journal of Molecular Endocrinology 32 627-648.

Imaki T, Nahan JL, Rivier C, Sawchenko PE \& Vale W 1991 Differential regulation of corticotropin-releasing factor mRNA in rat brain regions by glucocorticoids and stress. Journal of Neuroscience 11 585-599.

Imaki T, Shibasaki T, Hotta M \& Demura H 1992 Early induction of c-fos precedes increased expression of corticotropin-releasing factor messenger ribonucleic acid in the paraventricular nucleus after immobilization stress. Endocrinology 131 240-246.

Imaki T, Xiao-Quan W, Shibasaki T, Yamada K, Harada S, Chikada N, Naruse M \& Demura H 1995 Stress-induced activation of neuronal activity and corticotropin-releasing factor gene expression in the paraventricular nucleus is modulated by glucocorticoids in rats. Journal of Clinical Investigation 96 231-238.

Imaki T, Shibasaki T, Chikada N, Harada S, Naruse M \& Demura H 1996 Different expression of immediate-early genes in the rat paraventricular nucleus induced by stress: relation to corticotropin-releasing factor gene transcription. Endocrine Journal 43 629-638.

McClennen SJ, Cortright DN \& Seasholtz AF 1998 Regulation of pituitary corticotropin-releasing hormone-binding protein messenger ribonucleic acid levels by restraint stress and adrenalectomy. Endocrinology 139 4435-4441. 
McLean M, Bisits A, Davies J, Woods R, Lowry P \& Smith R 1995 A placental clock controlling the length of human pregnancy. Nature Medicine 1 460-463.

Nielsen H \& Krogh A 1998 Prediction of signal peptides and signal anchors by a hidden Markov model. Proceedings of the International Conference on Intelligent Systems for Molecular Biology 6 122-130.

Nielsen H, Engelbrecht J, Brunak S \& von Heijne G 1997 A neural network method for identification of prokaryotic and eukaryotic signal peptides and prediction of their cleavage sites. International Journal of Neural Systems 8 581-599.

Olivereau M \& Olivereau J 1988 Localization of CRF-like immunoreactivity in the brain and pituitary of teleost fish. Peptides 9 13-21.

Pepels PP, Van Helvoort H, Wendelaar Bonga SE \& Balm PH 2004 Corticotropin-releasing hormone in the teleost stress response: rapid appearance of the peptide in plasma of tilapia (Oreochromis mossambicus). Journal of Endocrinology 180 425-438.

Petraglia F, Potter E, Cameron VA, Sutton S, Behan DP, Woods RJ, Sawchenko PE, Lowry PJ \& Vale W 1993 Corticotropin-releasing factor-binding protein is produced by human placenta and intrauterine tissues. Journal of Clinical Endocrinology and Metabolism 77 919-924.

Potter E, Behan DP, Fischer WH, Linton EA, Lowry PJ \& Vale WW 1991 Cloning and characterization of the cDNAs for human and rat corticotropin releasing factor-binding proteins. Nature 349 $423-426$.
Pottinger T \& Moran T 1993 Differences in plasma cortisol and cortisone dynamics during stress in two strains of rainbow trout (Oncorhynchus mykiss). Journal of Fish Biology 43 121-130.

Seasholtz AF, Valverde RA \& Denver RJ 2002 Corticotropinreleasing hormone-binding protein: biochemistry and function from fishes to mammals. Journal of Endocrinology 175 89-97.

Ungless MA, Singh V, Crowder TL, Yaka R, Ron D \& Bonci A 2003 Corticotropin-releasing factor requires CRF binding protein to potentiate NMDA receptors via CRF receptor 2 in dopamine neurons. Neuron 39 401-407.

Wendelaar Bonga SE 1997 The stress response in fish. Physiological Reviews 77 591-625.

Yulis CR \& Lederis K 1987 Co-localization of the immunoreactivities of corticotropin-releasing factor and arginine vasotocin in the brain and pituitary system of the teleost Catostomus commersoni. Cell and Tissue Research 247 267-273.

Zhao XJ, Hoheisel G, Schauer J \& Bornstein SR 1997 Corticotropin-releasing hormone-binding protein and its possible role in neuroendocrinological research. Hormone and Metabolic Research 29 373-378.

Received 18 April 2005

Accepted 22 April 2005

Made available online as an Accepted Preprint

6 May 2005 